\title{
LEISURE INDUSTRY AND ITS VALUE FOR REGIONAL SOCIO-ECONOMIC DEVELOPMENT
}

\author{
Nataliya GUSEVA \\ V. N. Karazin Kharkiv National University, Ukraine \\ gusewa-nv@yandex.ua
}

\begin{abstract}
Free time and forms of its spending, rather than material things, increasingly become one of the central values of the modern person. Researchers use different terms to define free time: leisure, recreation, entertainment, etc. Leisure is an inherent component of a person vital activity, and leisure industry became one of the most profitable types of economic activity. Thus leisure industry should become the prior economic sector in our country and needs more detail research.

Leisure industry consists of the set of different business entities (leisure institutions) providing services aimed at fulfilling person's needs in free time from work. The institutions list of leisure industry is quite big. It causes the necessity of their classification. Therefore, by the level of involvement in leisure activities all leisure institutions are divided into 3 groups, providing leisure services as an additional, main or peripheral activity respectively. Among institutions providing leisure services as the main activity, functional sub-groups are sports, entertainment, cultural, educational, and spectator institutions. Other classification criteria are visitor's age, administrative-territorial status, accessibility, period of functioning, ownership, capacity, cost, service level, establishment time, visitor behavior, etc.

Leisure industry has significant influence on economic and social development of a country and its regions.

Key words: free time, leisure, leisure types, leisure industry, leisure industry structure, leisure institutions, classification of leisure institutions.
\end{abstract}

DOI: http://dx.doi.org/10.17721/2413-7154/2016.75.55-62

UDC: 911.3

\section{ІНДУСТРІЯ ДОЗВІЛЛЯ ТА ІІЇ ЗНАЧЕННЯ ДЛЯ СОЦІАЛЬНО-ЕКОНОМІЧНОГО РОЗВИТКУ РЕГІОНУ}

\author{
Наталія ГУСЄВА \\ Харківський начіональний університет імені В. Н. Каразіна, Україна \\ gusewa-nv@yandex.ua
}

\begin{abstract}
Анотація: Однією з центральних цінностей сучасної людини дедалі більше стають не матеріальні речі, а вільний час, форми його проведення. Для позначення вільного часу дослідники використовують різні поняття - дозвілля, відпочинок, розваги, рекреація тощо. Дозвілля $\epsilon$ невід'ємною складовою життєдіяльності людини, а індустрія дозвілля перетворилась у найбільш прибутковий вид економічної діяльності. 3 огляду на це, індустрія дозвілля в нашій країні має стати пріоритетною сферою економіки та потребує ретельного дослідження.

Індустрія дозвілля представляє собою сукупність різних суб'єктів господарської діяльності (закладів дозвілля), які надають послуги, спрямовані на задоволення потреб людини у вільний від роботи час. Перелік закладів, що можна віднести до індустрії дозвілля, досить значний. Це обумовлює необхідність їх класифікації. Так, за рівнем залученості до дозвіллєвої діяльності всі заклади дозвілля поділяються на 3 групи - заклади, для яких дозвілля є додатковою, основною та побічною діяльністю. Серед закладів, для яких дозвілля $\epsilon$ основною діяльністю, за функцією виділяють спортивні і спортивно-видовищні, розважальні, культурно-просвітницькі, видовищні заклади. Іншими класифікаційними критеріями закладів дозвілля $\epsilon$ вік відвідувачів, адміністративно-територіальний статус, доступність, термін дії, форма власності, місткість, вартість, рівень сервісу, період виникнення, поведінка відвідувачів тощо.

Індустрія дозвілля має важливий вплив на економічний та соціальний розвиток країни та ї̈ регіонів.

Ключові слова: вільний час, дозвілля, види дозвілля, індустрія дозвілля, структура індустрії дозвілля, заклади дозвілля, класифікація закладів дозвілля.
\end{abstract}

DOI: http://dx.doi.org/10.17721/2413-7154/2016.75.55-62

удк: 911.3

Вступ. У постіндустріальному суспільстві головними критеріями успіху й життєвого добробуту давно вже стали не володіння квартирою, дачею або машиною, а комфорт, ексклюзивність i якість життя, вимоги до яких стають дуже високими. Вільний час, важливою складовою якого

(C) Н. Гусєва є дозвілля, став однією з центральних цінностей, а форми його проведення - усе більш витонченими. Більше того, дозвілля розглядається як невід'ємна складова життєдіяльності людини, необхідна для відновлення фізичних сил, отримання задоволення, накопичення творчих сил та інтелектуального прориву тощо, а індустрія дозвілля перетворилась у найбільш прибутковий вид економічної діяльності. 


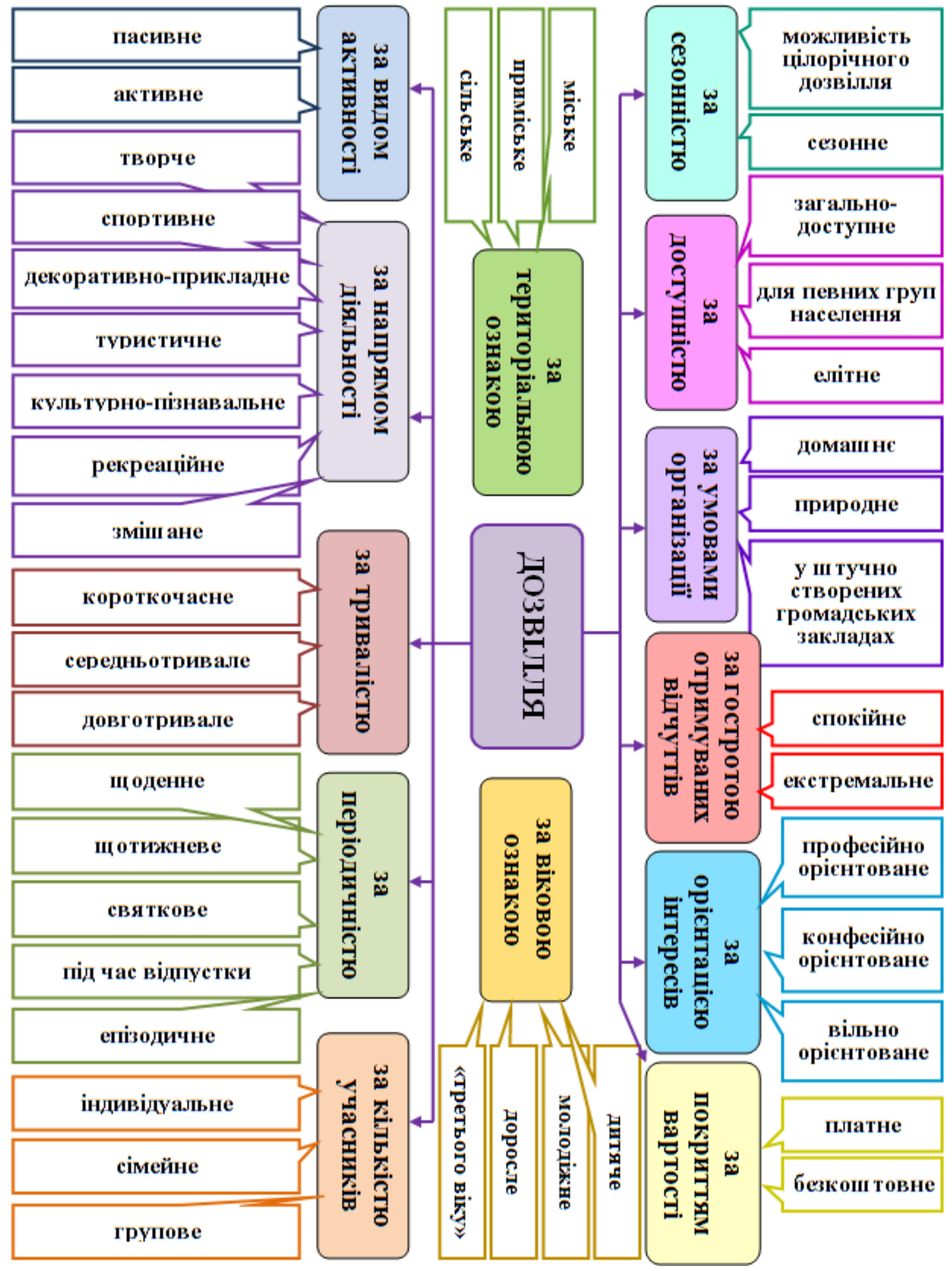

Рис. 1. Класифікація дозвілля (побудовано за $[1,3,4])$. 
Зарубіжна статистика свідчить, що щорічний прибуток індустрії дозвілля в сучасному світі складає більше 200 млрд. дол. Щороку ця сума зростає на $10-15 \%$ залежно від демографічних змін, технологічних інновацій, глобалізації соціально-культурних процесів [5]. Проте, якщо в країнах Західної Свропи та США індустрія дозвілля бурхливо розвивається ще 3 50-х років XX ст., то на пострадянському просторі, в т. ч. в Україні, ця галузь лише починає формуватися. 3 огляду на це, індустрія дозвілля в нашій країні має стати пріоритетною сферою економіки та потребує ретельного дослідження 3 боку різних фахівців, у т. ч. й у географічному аспекті як на державному, так і на регіональному рівнях.

Теоретико-методологічні основи дослідження. Науковими та прикладними питаннями дослідження індустрії дозвілля займаються фахівці різних наукових напрямів, зокрема соціологи, економісти, психологи, педагоги, культурологи тощо. Так, у працях зарубіжних учених Дж. Булларо, Д. Гоббса, Л. Джеймсона, Дж. Дюмазедьє, К. Едінгтона, Дж. Келлі та ін. розкривається сутність і природа рекреації й дозвілля, принципи формування рекреаційної та дозвіллєвої індустрії, взаємозв'язок комерційних і некомерційних дозвіллєвих послуг, що надаються в сфері дозвілля [5]. Серед вітчизняних учених-географів можна назвати роботи В. Ф. Кіфяка, О. О. Любіцевої, І. Г. Мельник, В. С. Пацюка, М. М. Поколодної, І. В. Смаль, Н. В. Фоменка та інших.

Мета дослідження - розглянути індустрію дозвілля як галузь економіки та розкрити ii значення для соціально-економічного розвитку регіону. Для досягнення мети були поставлені наступні завдання:

- розкрити зміст поняття «дозвілля»;

- розглянути індустрію дозвілля як галузь економіки;

- визначити структуру індустрії дозвілля;

- провести класифікацію закладів дозвілля за різними критеріями;

- розкрити значення індустрії дозвілля для соціально-економічного розвитку регіону.

Опис методики дослідження та здобутих емпіричних даних. Соціальна практика свідчить, що бюджет часу людини складається 3 трьох органічно взаємопов'язаних, але якісно різних компонентів: робочого часу, необхідного позаробочого та вільного часу. Вільний час - це масив часу, не пов'язаний 3 виконанням людиною професійної діяльності, задоволенням фізіологічних потреб та 3 діяльністю вимушеного характеру i який спрямований, 3 одного боку, на розширене відновлення сил, 3 іншого - на духовне й фізичне самовдосконалення. За оцінками фахівців, на вільний час (у такому його визначенні) припадає близько чверті суспільного часу. У вільний час людина може займатися громадською роботою, вихованням, самоосвітою, мистецтвом, спортом тощо [2].
Важливою частиною вільного часу є дозвілля. Проблематика дозвілля вивчається науковцями різних галузей i напрямів: соціологами, психологами, педагогами, демографами, економістами, архітекторами, культурологами тощо, що визначає різноманітність підходів до самого поняття «дозвілля» - психологічний, філософський, соціологічний, педагогічний, економічний, географічний тощо. Так, географи розглядають поняття «дозвілля» через призму просторової диференціації та територіальної взаємодії суб'єктів дозвілля.

Серед всієї різноманітності визначень поняття «дозвілля», найбільш вдалим є наступне: дозвілля - це час, вільний від роботи й рутинних домашніх обов'язків i придатний для відновлення сил, розслаблення, хобі, відпочинку, культурних та художніх занять, а також діяльність людини у вільний час, спрямована на відпочинок та розвиток особистості.

Сучасне дозвілля поділяється на багато типів в залежності від психологічних, освітніх, соціальних, рекреаційних, фізіологічних та естетичних компонентів. У зв'язку 3 цим дозвілля можна класифікувати за різними критеріями - кількістю учасників та їх віком, характером організації, сезонністю, територіальною ознакою, тривалістю, метою, доступністю, умовами організації, гостротою отримуваних емоцій, орієнтацією інтересів, періодичністю та покриттям вартості дозвілля (рис. 1).

У зв'язку з надзвичайним різноманіттям дозвілля та закладів, що займаються його організацією, значною прибутковістю сфери надання дозвіллєвих послуг, їх масовим, індустріальним виробництвом та, відповідно, масовим споживанням, для позначення цієї сфери як галузі економіки все частіше використовують термін «індустрія дозвілля».

Індустрія дозвілля в різних країнах має свої назви: «індустрія дозвілля», «дозвіллєво-рекреаційна сфера» - в США та Великій Британії, «сфера вільного часу» - в Німеччині, «анімація» - в Італії, Туреччині, Франції. Такі назви є історично зумовленими та відображають розуміння дозвіллєвої сфери в контексті соціальної, політичної, економічної та культурної ситуації кожної країни [7].

Незважаючи на те, що термін «індустрія дозвілля» було введено до наукового обігу ще в середині XX ст., серед дослідників і сьогодні немає єдиної думки стосовно змістовного наповнення та логічного обсягу означуваного ним явища. У більшості випадків під індустрісю дозвілля розуміють сукупність різних суб'єктів господарської діяльності (закладів дозвілля), які надають послуги, спрямовані на задоволення потреб людини у вільний від роботи час [6]. Оскільки потреби людини під час дозвілля дуже різноманітні (відпочити, відновити втрачені фізичні і духовні сили, покращити стан здоров'я, формувати i розвивати особистість, отримати позитивні емоції, розвивати культуру, інтелектуальні здібності тощо) перелік закладів, що можна віднести до індустрії дозвілля, досить значний. Це обумовлює необхідність їх класифікації. 
Згідно [6] всі заклади дозвілля за рівнем залученості до дозвіллєвої діяльності поділяються на три групи - заклади, для яких дозвілля є додатковою, основною та побічною діяльністю (рис. 2).

Важливою класифікаційною ознакою є функція, яку виконує заклад дозвілля, тобто на задоволення яких потреб відпочиваючих спрямована їх діяльність. За цим критерієм заклади дозвілля, для яких дозвілля $є$ основною діяльністю, можна поділити на 4 групи (рис. 3):

1) спортивні та спортивно-видовищні заклади, до яких відносяться спеціально обладнані майданчики та споруди, які дозволяють здійснювати дозвіллєву діяльність у спортивному напрямі та спостерігати за масовими спортивними заходами, змаганнями, іграми тощо (спортивні клуби, зали, організації, секції, комплекси, стадіони, фітнес-клуби i фітнес-центри, плавальні басейни, льодові арени, майданчики для гри в гольф, іподроми, треки тощо);

2) розважальні заклади (розважальні, торгівельно-розважальні та культурно-розважальні центри i комплекси, казино, парки атракціонів, луна-парки, гральні майданчики, нічні клуби i танцювальні (дискотечні) зали та майданчики, парки культури і відпочинку, аквапарки та ін.);

3) видовищні заклади (кінотеатри та інші демонстратори фільмів - кіно- і відеоустановки, зали, салони, майданчики, кімнати тощо; театри, філармонії, концертні зали, цирки, зоопарки та ін.);

4) культурно-просвітницьькі заклади (музеї, бібліотеки, галереї та виставкові центри, планетарії, заклади клубного типу - клуби, будинки і палаци культури, молодіжні центри, будинки народної творчості (фольклору), центри дитячої творчості, будинки мистецтв та ін.). До цієї групи закладів відносяться також позашкільні навчальновиховні заклади та школи естетичного виховання. Прикладами таких закладів виступають школи мистецтв (народної творчості), центри, палаци, будинки, клуби туристсько-краєзнавчої, науковотехнічної, художньої, еколого-натуралістичної творчості тощо [3].

Також до закладів дозвілля часто відносять оздоровчі заклади - санаторії, пансіонати, санаторнокурортні комплекси, будинки відпочинку тощо; заклади розміщення (готелі, мотелі, туристичні центри, комплекси і бази, будинки відпочинку тощо), клуби-ресторани, кафе-клуби, сімейні рекреаційні комплекси i центри дозвілля, державні зони відпочинку та історико-культурні місця та ін. [5].

Аналіз особливостей функціонування закладів дозвілля, дозволяє зробити їх класифікацію за різними ознаками (табл. 1, рис. 4).

Виходячи зі структури індустрії дозвілля розглянемо ii значення в господарстві адміністративно-територіальних одиниць локального рівня. Більшість регіонів України на сьогоднішній день мають ряд невирішених соціально-економічних проблем, що безпосередньо впливають на їх господарський розвиток та складну демографічна ситуацію. Так, у більшості регіонів України продовжується закриття підприємств, що призводить до зменшення надходжень до місцевих бюджетів, зростання рівня безробіття, зниження доходів місцевого населення. Ці процеси, зазвичай, впливають також на показники злочинності, зменшення народжуваності та ведуть до збільшення соціальної напруги в суспільстві.

Вирішити ряд соціально-економічних проблем регіону, на нашу думку, можливо за рахунок більш інтенсивного розвитку індустрії дозвілля, що дозволить:

- створити нові робочі місця та підвищити рівень зайнятості місцевого населення;

- збільшити надходження до місцевих бюджетів;

- покращити якість життя населення за рахунок задоволення їх найрізноманітніших дозвіллєвих потреб, урізноманітнення форм проведення дозвілля, реалізації особистого освітнього й творчого потенціалу i, як результат, - покращити якість відтворення робочої сили;

- покращити роботу суміжних галузей, зокрема, транспорту, торгівлі, будівництва, сфери послуг тощо;

- збільшити попит на місцеву сільськогосподарську i харчову продукцію та товари місцевого виробництва;

- пропагувати здоровий спосіб життя за рахунок розширення мережі спортивних закладів;

- поліпшити збереження місцевих пам'яток культури, історії, архітектури, мистецтва;

- поліпшити збереження екологічної системи території тощо.

Таким чином, за рахунок розвитку індустрії дозвілля в межах адміністративно-територіальних одиниць локального рівня можливе зростання економічного потенціалу місцевих територіальних громад, що створить передумови для підвищення якості життя населення та позитивних структурних змін у господарському комплексі регіону.

Крім того, індустрія дозвілля відіграє провідну роль у формуванні інвестиційної привабливості регіону, бо постає перспективною галуззю для інвесторів, що дозволяє збільшити притік капіталовкладень в економіку регіону.

В той же час, розвиток індустрії дозвілля та безпосередньо пов'язаного з нею туризму на певній території має й деякі негативні прояви, зокрема:

- можуть виникати конфлікти між місцевим населенням та відпочиваючими;

- ймовірна комерціалізація певних видів діяльності, які раніше здійснювались безоплатно (поява приватних пляжів, ставків, платне відвідування закладів дозвілля);

- можливе зростання числа відхилень від загальноприйнятих норм суспільної поведінки (зростання злочинності, хуліганства, алкоголізму, проституціï).

Крім того, зростання антропогенного навантаження на природні комплекси 3 боку відпочиваючих може спричиняти негативний вплив на довкілля цих територій. Проте, більшість негативних впливів індустрії дозвілля можна запобігти за рахунок комплексного планування iï 


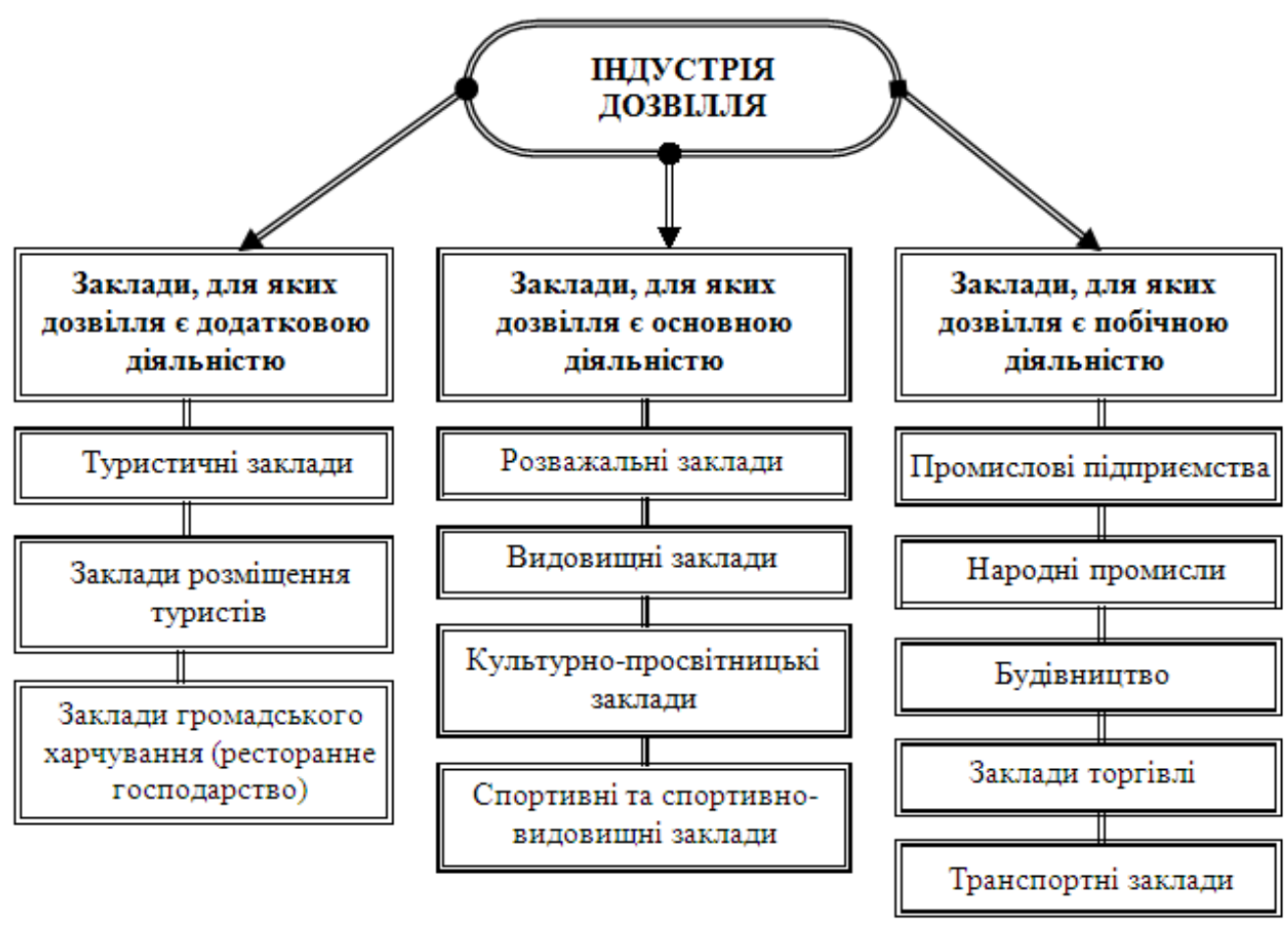

Рис. 2. Класифікація закладів дозвілля за рівнем залученості до дозвіллєвої діяльності (побудовано за [6]).

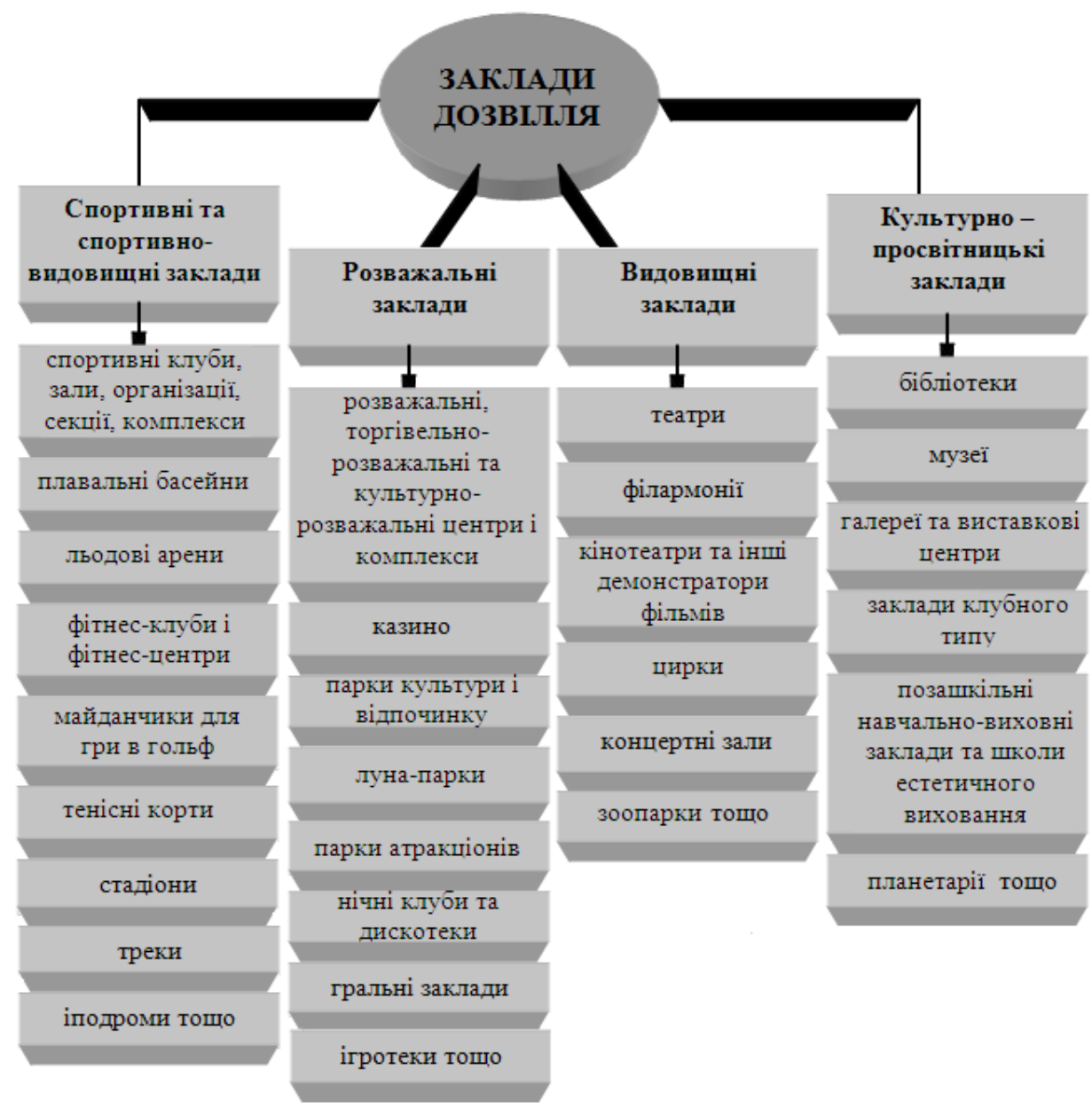

Рис. 3. Класифікація закладів дозвілля за функціями (побудовано за [3, 6]). 


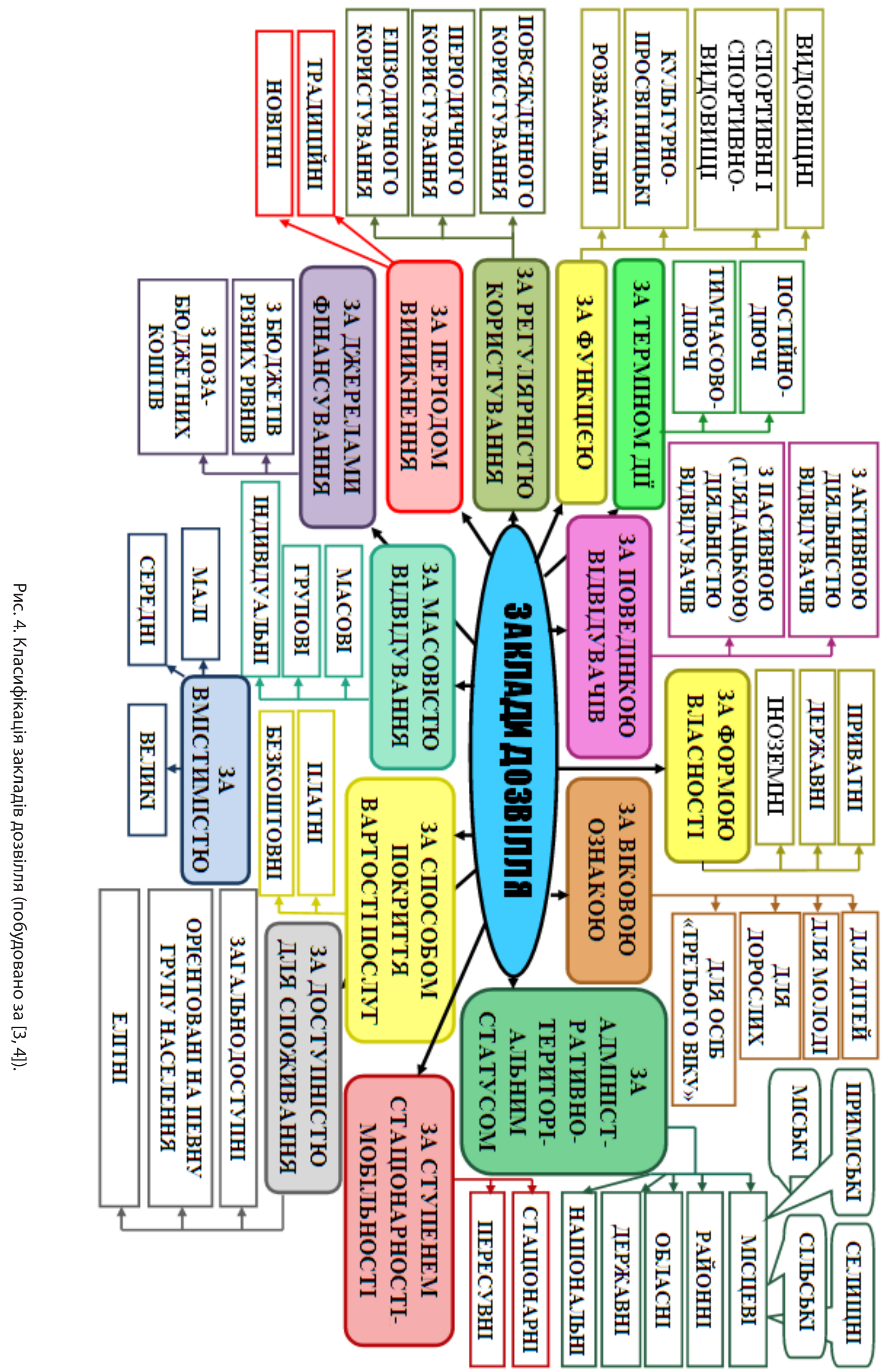


Класифікація закладів дозвілля (складено за $[3,4]$ )

\begin{tabular}{|c|c|}
\hline Ознака & Види закладів дозвілля \\
\hline вік відвідувачів & для дітей, для молоді, для дорослих, для осіб похилого віку \\
\hline $\begin{array}{l}\text { адміністративно-територіальний } \\
\text { статус }\end{array}$ & національні, державні, обласні, районні, місцеві - міські, селищні, сільські \\
\hline функція & $\begin{array}{l}\text { розважальні, культурно-просвітницькі, спортивні та спортивні видовищні, } \\
\text { видовищні }\end{array}$ \\
\hline доступність & загальнодоступні, доступні для певних груп населення, елітні \\
\hline термін дії & постійнодіючі, тимчасоводіючі \\
\hline форма власності & приватні, державні, іноземні, спільні \\
\hline місткість & малі (до 50 осіб), середні (50-500), великі (понад 500) \\
\hline вартість & платні, безкоштовні \\
\hline рівень сервісу & $\begin{array}{l}\text { визначається відповідно до якості інженерно-технічного оснащення, рівня } \\
\text { обслуговування, набору основних і додаткових послуг }\end{array}$ \\
\hline $\begin{array}{l}\text { розміщення за відношенням до } \\
\text { інших закладів даної сфери }\end{array}$ & $\begin{array}{l}\text { одиничні, групові (на невеликій території розміщено декілька закладів), комплексні } \\
\text { (декілька закладів розміщено під одним дахом - різноманітні розважальні центри і } \\
\text { комплекси) }\end{array}$ \\
\hline період виникнення & традиційні, новітні \\
\hline поведінка відвідувачів & з активною та пасивною (глядацькою) діяльністю глядачів \\
\hline стаціонарність & стаціонарні, пересувні \\
\hline масовість відвідування & масові, групові, індивідуальні \\
\hline джерела фінансування & з бюджетів різних рівнів, з позабюджетних коштів \\
\hline регулярність користування & повсякденного, періодичного, епізодичного користування \\
\hline
\end{tabular}

розвитку, посилення державного контролю за цим видом діяльності.

Висновки. Дозвілля як складне соціокультурне явище характеризується надзвичайним різноманіттям. Його можна класифікувати за цілим рядом критеріїв - віковою i територіальною ознакою, тривалістю, періодичністю, доступністю, сезонністю, напрямами діяльності, кількістю учасників тощо. У зв'язку з цим в сучасному суспільстві склалася розгалужена мережа закладів дозвілля, які відрізняються між собою функціями, поведінкою відпочиваючих, доступністю, вартістю, формою власності та фінансування тощо. Індустрія дозвілля включає розважальні, культурно- просвітницькі, спортивні, видовищні заклади, а також готельне господарство, клуби-ресторани, кафе-клуби; сімейні рекреаційні комплекси та центри дозвілля; державні зони відпочинку та історико-культурні місця тощо.

Індустрія дозвілля має важливий вплив на економічний та соціальний розвиток країни. Вона сприяє підвищенню якості життя за рахунок організації змістовного та різноманітного дозвілля, сприяє підвищенню рівня зайнятості населення, збільшує надходження до бюджетів різних рівнів, покращує роботу суміжних галузей господарства, сприяє збереженню пам'яток культури, історії, архітектури, мистецтва тощо.

\section{References:}

1. Golovko O. M., Kampov N. S., Mahlinec' S. S., Simočko G. V. Organizaciâ gotel'nogo gospodarstva [Organization of hospitality industry]. Kyiv, 2012, 338 p. (In Ukrainian).

2. Mel'nik Ì. G. Osnovi rekreacijnoï geografiï. [Foundations of recreational geography]. Lugansk, 2008,174 p. (In Ukrainian).

3. Moštakova N. V. Zakladi kul'turi âk osnovnì strukturnì elementi sferi kul'turi ta ïh klasifìkaciâ. [Cultural institutions as the main structural elements of the culture realm and their classification] «Region-2012: strategia

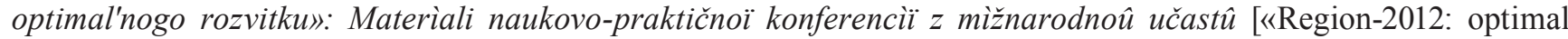
development strategy»: Materials of scientific-practical conference with international participation (Kharkiv, 2627 October 2012)]. V. N. Karazina Kharkiv National University, 2012, pp. 92-96. (In Ukrainian).

4. Pacûk V. Industrìâ dozvìllâ âk skladova turističnoï sferi [Industry of leisure as a component of tourist sphere]. Vìnik Kïvs'kogo nacional'nogo unìversitetu imeni Tarasa Ševčenka. Serîa Geografîa. [Bulletin of Taras Shevchenko National University of Kyiv. Series: Geography], 2008, Vip. 55, S. 51-52. (In Ukrainian).

5. Petrova İ. V. Sutnìst' ta osoblivostì stanovlennâ ìndustriï dozvillâ [The essence and the specificity of the leisure 
industry genesis]. Kul'tura ì sučasnist'. [Culture and Modernity]. 2009, \# 2, pp. 87-92. (In Ukrainian).

6. Rekreacionnyj biznes i industriâ dosuga. [Recreational business and industry of leisure]. Access mode: http:// mybiblioteka.su/7-88453.html. (In Russian).

7. Teoretičnì osnovi dozvillêvoï diâl'nostì u molodižnomu seredovisì [Theoretical foundations of leisure activities among young people]. Access mode: http://www.virtual.ks.ua/students/4759-theoretical-foundations-of-leisureactivity-among-young-people.html. (In Ukrainian). 